\title{
IMPLEMENTASI PROGRAM QUEST UNTUK MENGANALISIS BUTIR SOAL BAGI GURU-GURU SMP MUHAMMADIYAH 2 KARANGLEWAS
}

\author{
IMPLEMENTATION OF QUEST PROGRAM TO ANALYZE TEST ITEMS FOR SMP \\ MUHAMMADIYAH 2 KARANGLEWAS TEACHERS
}

\author{
${ }^{1}$ Hindayati Mustafidah, ${ }^{2}$ Harjono \\ ${ }^{1,2)}$ Teknik Informatika, Fakultas Teknik dan Sains, Universitas Muhammadiyah Purwokerto \\ J1. Raya Dukuhwaluh Purwokerto 53182 \\ ${ }^{1}$ fida.mustafidah@ump.ac.id \\ 2pakjono@gmail.com
}

\begin{abstract}
ABSTRAK
Pengukuran dan penilaian terhadap kegiatan pendidikan mutlak harus dilakukan khususnya hasil belajar. Tes merupakan salah satu instrument instrumen yang dapat digunakan untuk mengukur hasil belajar.Sebagai alat ukur, tes harus memiliki karakteristik valid, reliable, memiliki daya pembeda yang bagus, serta memiliki tingkat kesukaran yang representatif. Untuk mengetahui karakteristik ini, harus dilakukan analisis terhadap tes. Selama ini, kegiatan analisis tes jarang dilakukan dengan alasan kurangnya waktu dan tenaga, serta sulit dalam menggunakan rumus meskipun telah tersedia alat bantu komputer. Untuk mengatasi hal ini, dilaksanakan kegiatan pengabdian pada masyarakat memanfaatkan program QUEST untuk membantu melakukan asesmen terhadap kualitas soal tes.Kegiatan ini melibatkan guru-guru SMP Muhammadiyah 2 Karanglewas Kabupaten Banyumas sebagai mitra aktif. Pelaksanaan kegiatan dilakukan dengan metode pendidikan dan pelatihan dengan tahapan penyampaian materi kemudian dilanjutkan dengan praktik langsung mengoperasikan program QUEST dan cara membaca hasil keluaran program. Luaran dari kegiatan ini berupa sertifikat kompetensi atas target yang diharapkan yaitu guru memiliki kompetensi di salah satu bidang kompetensi pedagogik berupa kompetensi pemanfaatan teknologi berupa program QUEST dalam menganalisis butir soal tes. Indikator keberhasilan dari kegiatan ini dicapai dengan hasil 87\% dari mitra bias mengoperasikan program QUEST dan bisa melakukan analisis butir soal tes yang disusunnya untuk mengetahui apakah soal sudah memenuhi kategori soal yang baik atau belum.
\end{abstract}

Kata kunci: Instrumen Tes; Kompetensi Pedagogik; QUEST; Analisis Butir Soal

\begin{abstract}
Measurement and assessment of educational activities must be carried out, especially learning outcomes. The test is one instrument instrument that can be used to measure learning outcomes. As a measuring tool, tests must have the characteristics of valid, reliable, have a good distinguishing power, and have a representative level of difficulty. To find out these characteristics, an analysis of the test must be carried out. During this time, test analysis activities are rarely carried out for reasons of lack of time and energy, and it is difficult to use formulas even though computer aids are available. To overcome this, community service activities were carried out using the QUEST program to help assess the quality of test questions. This activity involved the teachers of Muhammadiyah 2 Karanglewas Middle School in Banyumas Regency as active partners. The implementation of the activities was carried out with education and training methods with the stage of material delivery then continued with the direct practice of operating the QUEST program and how to read the program output. The output of this activity is in the form of a competency certificate on the expected target, namely the teacher has competence in one of the fields of pedagogic competence in the form of technology utilization competency in the form of QUEST program in analyzing test items. The indicator of the success of this activity was achieved with the results of $87 \%$ of the partners being able to operate the QUEST program and could analyze the test items that were arranged to find out whether the question had fulfilled the good category or not.
\end{abstract}

Keywords: Test Instrument; Pedagogic Competence; QUEST; Analysis of Items 
Hindayati Mustafidah, Harjono

Implementasi Program QUEST Untuk Menganalisis Butir Soal Bagi Guru-Guru SMP Muhammadiyah 2 Karanglewas

\section{PENDAHULUAN}

Evaluasi pendidikan adalah kegiatan yang dilakukan dalam rangka mengukur dan menilai segala hal yang termasuk dalam kegiatan pendidikan termasuk di dalamnya hasil belajar. Salah satu instrumen yang dapat digunakan untuk mengukur hasil belajar adalah tes. Secara konseptual, Haladyna \& Rodriguez (2013) menyebutkan bahwa tes adalah alat ukur secara numerik yang diharapkan dapat menggambarkan tingkat atau jumlah konstruk yang seragam, pada kondisi standar. Sementara itu, Yusuf (2015) mengemukakan bahwa tes adalah sebuah prosedur sistematis untuk mengobservasi tingkah laku seseorang dan mendeskripsikannya dalam bentuk skala angka atau sistem kategori. Hal ini mengandung arti bahwa tes adalah sebuah tipe penilaian yang menggunakan prosedur tertentu untuk memeroleh informasi dan mengonversikan informasi tersebut ke dalam bentuk angka atau skor. Hal ini juga dikemukakan oleh Uno \& Koni (2012) bahwa tes adalah seperangkat rangsangan (stimuli) yang diberikan kepada seseorang (siswa) dengan maksud untuk mendapatkan jawaban-jawaban yang menjadi dasar bagi penetapan skor angka. Skor yang didasarkan pada sampel yang representatif dari tingkah laku pengikut tes (siswa) merupakan indikator tentang seberapa jauh siswa tersebut memiliki karakteristik yang sedang diukur.

Sebelum suatu tes hasil belajar suatu mata pelajaran digunakan dalam pengukuran, tes hasil belajar tersebut harus telah dipertimbangkan secara masak. Tes hasil belajar tersebut harus sudah dikenal ciri-cirinya menurut tipenya, telah direncanakan, dan telah disusun berdasarkan petunjuk-petunjuk penyusunannya. Setelah tes hasil belajar tersebut digunakan dalam suatu pengukuran, maka seorang guru akan memperoleh umpan balik tentang mutu tes hasil belajar tersebut.Umpan balik mengenai mutu tes hasil belajar akan diperoleh, apabila seorang guru memeriksa skor-skor yang diperoleh dari suatu pengukuran tersebut.

Dikmenum (2008) menyatakan bahwa kegiatan analisis butir soal bertujuan untuk: (1) menentukan soal-soal yang cacat atau tidak berfungsi penggunaannya; (2) meningkatkan butir soal melalui tiga komponen analisis yaitu tingkat kesukaran, daya pembeda, dan pengecoh soal, serta meningkatkan pembelajaran melalui ambiguitas soal dan keterampilan tertentu yang menyebabkan peserta didik sulit. Di samping itu, butir soal yang telah dianalisis dapat memberikan informasi kepada peserta didik dan guru. Sementara itu Uno dan Koni (2012) menyatakan bahwa tujuan dari analisis butir soal adalah untuk mengadakan identifikasi soal-soal yang baik, kurang baik, jelas, dan yang kurang jelas. Dengan analisis butir soal dapat diperoleh informasi tentang kejelekan sebuah soal dan petunjuk untuk mengadakan perbaikan. Terdapat dua cara melakukan analisis butir soal yaitu analisis secara kualitatif dan kuantitatif.

Sebelum suatu tes hasil belajar suatu mata pelajaran digunakan dalam pengukuran, tes hasil belajar tersebut harus telah dipertimbangkan secara masak. Tes hasil belajar tersebut harus sudah dikenal ciri-cirinya menurut tipenya, telah direncanakan, dan telah disusun berdasarkan petunjuk-petunjuk penyusunannya. Setelah tes hasil belajar tersebut digunakan dalam suatu pengukuran, maka seorang guru akan memperoleh umpan balik tentang mutu tes hasil belajar tersebut. Umpan balik mengenai mutu tes hasil belajar akan diperoleh, apabila seorang guru memeriksa skor-skor yang diperoleh dari suatu pengukuran tersebut.

Berdasarkan beberapa informasi yang disampaikan oleh Suwarsito \& Sutomo (2009) dan Mustafidah \& Pinandita (2011), soal tes yang disusun khususnya di Kabupaten Banyumas jarang sekali dilakukan evaluasi atau bahkan tidak dievaluasi sama sekali. Salah satu penyebabnya karena jika menggunakan penghitungan secara manual banyak menggunakan rumus sehingga sangat menyita waktu terlebih jika kurang teliti akan memengaruhi hasil perhitungan. Alasan yang paling penting mengapa tidak dilakukannya analisis soal adalah kekhawatiran akan 
bocornya soal sebelum soal itu benar-benar diujikan kepada siswa. Hal ini disinyalir sebagai salah satu sebab masih belum berkualitasnya soal untuk diujikan ke siswa. Berdasarkan beberapa survei yang dilakukan di sekolah-sekolah di Kabupaten Banyumas, Purbalingga, dan Tegal untuk tingkat SLTA, SLTP, dan SD, ternyata soal belum memenuhi standar sebagai soal yang berkualitas sebagaimana terlihat pada Tabel 1 .

Selain data seperti dalam Tabel 1, beberapa hasil penelitian dilaporkan bahwa: (1) soal ulangan akhir semester bidang studi Kimia kelas X SMA Negeri 1 Pati tahun ajaran 2007/2008 memiliki reliabilitas tinggi dengan harga $\mathrm{r} 11=0,78$ dan $85,71 \%$ butir soal valid, namun tingkat kesukaran belum proporsional (Nuswowati et al., 2010) dan (2) karakteristik soal UN Bahasa Inggris SMK di Kabupaten Tabalong keefektifan ditraktor hasilnya hanya $40 \%$ atau 20 butir yang dapat dikategorikan baik meskipun dari estimasi reliabilitas termasuk kategori tinggi (Hanafi and Suhardi, 2014). Dalam mata pelajaran ekonomi juga dilaporkan bahwa soal Ujian Akhir Sekolah Produktif Pemasaran Kelas XII Pemasaran SMK Negeri 9 Semarang (Studi Pada Tahun Ajaran 2013/2014) termasuk kategori validitas sangat rendah (54\%), tergolong soal tidak reliabel (alpha $=0.63)$, daya pembeda jelek $(56 \%)$, tingkat kesukaran sedang (40\%), dan termasuk kategori dengan efektifitas distraktor yang jelek (62\% tidak berfungsi) (Raharja, 2014). Kondisi yang tidak jauh berbeda disampaikan pula oleh Rahmasari dan Ismiyati (2016) bahwa mata pelajaran Pengantar Administrasi Perkantoran kelas XI SMK Gatra Praja Pekalongan tahun ajaran 2014/2015 reliabilitas soal pilihan ganda sebesar 0,68 artinya soal tidak reliabel, $55 \%$ butir soal sedang, daya pembeda $25 \%$ butir soal sangat jelek, dengan fungsi distraktor sebesar $18,75 \%$ tidak berfungsi.

Tabel 1. Hasil Evaluasi terhadap Soal Tes di Beberapa Sekolah di Kabupaten Banyumas, Purbalingga, dan Tegal

\begin{tabular}{cllc}
\hline $\begin{array}{c}\text { Jumlah } \\
\text { Butir }\end{array}$ & $\begin{array}{c}\text { Klasifikasi dalam Taksonomi } \\
\text { Revisi Bloom }\end{array}$ & \multicolumn{1}{c}{ Daya Beda Soal } & $\begin{array}{c}\text { Reliabilitas Soal } \\
(\boldsymbol{\alpha}=\mathbf{5 \%})\end{array}$ \\
\hline 32 & $\mathrm{C} 1: 21.875 \% \mathrm{C} 2: 9.375 \%$ & $\mathrm{SR}: 58.064 \% \mathrm{R}: 32.258 \%$ & 0.425 \\
& $\mathrm{C} 3: 59.375 \% \mathrm{C} 4: 9.375 \%$ & $\mathrm{~S}: 6.452 \% \mathrm{~T}: 3.226 \%$ & (reliabel) \\
32 & $\mathrm{C} 1: 12.5 \% \mathrm{C} 2: 6.25 \%$ & $\mathrm{SR}: 40.625 \% \mathrm{R}: 25.000 \%$ & 0.549 \\
& $\mathrm{C} 3: 71.875 \% \mathrm{C} 4: 9.375 \%$ & $\mathrm{~S}: 34.375 \%$ & 0.259 \\
30 & $\mathrm{C} 1: 13.333 \% \mathrm{C} 2: 6.667 \%$ & $\mathrm{SR}: 50.000 \% \mathrm{R}: 23.333 \%$ & $\mathrm{~S}: 26.667 \%$ \\
& $\mathrm{C} 3: 70 \% \mathrm{C} 4: 10 \%$ & $\mathrm{SR}: 35.484 \% \mathrm{R}: 45.161 \%$ & (tidak reliabel) \\
32 & $\mathrm{C} 1: 21.875 \% \mathrm{C} 2: 9.375 \%$ & $\mathrm{~S}: 19.355 \%$ & 0.464 \\
& $\mathrm{C} 3: 59.375 \% \mathrm{C} 4: 9.375 \%$ & $\mathrm{SR}: 53.125 \% \quad \mathrm{R}: 37.500 \%$ & (reliabel) \\
32 & $\mathrm{C} 1: 12.5 \% \mathrm{C} 2: 6.25 \%$ & $\mathrm{~S}: 9.375 \%$ & 0.268 \\
& $\mathrm{C} 3: 71.875 \% \mathrm{C} 4: 9.375 \%$ & $\mathrm{SR}: 53.333 \% \mathrm{R}: 36.667 \%$ & 0.086 \\
30 & $\mathrm{C} 1: 13.333 \% \mathrm{C} 2: 6.667 \%$ & $\mathrm{~S}: 10.000 \%$ & (tidak reliabel) \\
& $\mathrm{C} 3: 70 \% \mathrm{C} 4: 10 \%$ & $\mathrm{SR}: 30 \% \mathrm{R}: 34 \%$ & (tidak reliabel) \\
50 & $\mathrm{C} 2: 30 \% \mathrm{C} 3: 58 \%$ & $\mathrm{~S}: 30 \% \mathrm{~T}: 6 \%$ & 0.818 \\
& $\mathrm{C} 4: 12 \%$ & $\mathrm{SR}: 16 \% \mathrm{R}: 36 \%$ & (reliabel) \\
50 & $\mathrm{C} 2: 30 \% \mathrm{C} 3: 58 \%$ & $\mathrm{~S}: 44 \% \mathrm{~T}: 4 \%$ & 0.882 \\
& $\mathrm{C} 4: 12 \%$ & $\mathrm{SR}: 35 \% \mathrm{R}: 40 \%$ & 0.370 \\
20 & $\mathrm{C} 1: 50 \% \mathrm{C} 2: 30 \%$ & $\mathrm{~S}: 20 \% \mathrm{~T}: 5 \%$ & (reliabel) \\
& $\mathrm{C} 3: 10 \% \mathrm{C} 4: 10 \%$ & $\mathrm{SR}: 58 \% \mathrm{R}: 38 \%$ & 0.45 \\
50 & $\mathrm{C} 1: 40 \% \mathrm{C} 2: 38 \%$ & $\mathrm{~S}: 4 \%$ & (tidak reliabel) \\
& $\mathrm{C} 3: 8 \% \mathrm{C} 4: 14 \%$ & $\mathrm{SR}: 60 \% \mathrm{R}: 20 \%$ & (reliabel) \\
20 & $\mathrm{C} 1: 20 \% \mathrm{C} 2: 35 \%$ & $\mathrm{~S}: 15 \% \mathrm{~T}: 5 \%$ & 0.520 \\
& $\mathrm{C} 4: 45 \%$ & (reliabel)
\end{tabular}

Sumber: (Dwiningsih, 2006), (Hani, 2006), (Sari, 2006), (Bennyarsih, 2006). 
Keterangan:
C1: mengetahui
SR: Sangat Rendah
C2: memahami
$\mathrm{R}:$ Rendah
C3: mengaplikasikan
S: Sedang
C4: menganalisis
T: Tinggi
C5: mengevaluasi
C6: mencipta

Meskipun dari data pada Tabel 1 diketahui bahwa ternyata soal-soal yang disusun belum semua memenuhi standar kualitas yang diharapkan, namun belum ada usaha yang nyata untuk memperbaikinya. Demikian juga hasil survei lapangan berupa wawancara dengan beberapa tenaga pengajar (guru) di Kabupaten Banyumas, jarang sekali bahkan belum pernah melakukan analisis atau evaluasi terhadap soal-soal yang disusun untuk mengetahui kualitasnya sebagai alat ukur bagi pembelajaran yang dilakukan. Bahkan hasil kajian yang dilakukan oleh (Widodo, 2010) disampaikan bahwa pada tahun pelajaran 2008/2009 seluruh guru SD, SMP, SMA BPK PENABUR Tasikmalaya tidak melakukan analisis soal tes formatif. Hanya sebagian kecil guru (SD dua orang, SMP satu orang, dan SMA dua orang) yang melaksanakan analisis butir soal pada tes sumatif atau tes evaluasi akhir semester. Padahal analisis soal tes merupakan bagian yang sebenarnya tidak boleh dipisahkan dari tahapan penilaian. Hal ini disebabkan untuk mengetahui tingkat keakuratan soal sebagai alat ukur harus dilakukan ujicoba terlebih dahulu sehingga terlalu menyita waktu, tenaga, dan pikiran padahal waktu yang tersedia sangat terbatas sedangkan tugas dan kegiatan yang lain masih banyak yang belum dikerjakan.

Situasi seperti yang telah disampaikan juga terjadi pada guru-guru di SMP Muhammadiyah 2 Karanglewas. Guru-guru di sekolah ini sebagian telah melakukan analisis butir soal, namun masih terkendala pada sarana yang digunakan. Beberapa guru menggunakan perhitungan manual (kalkulator), beberapa guru telah menggunakan program komputer yaitu ANATES. Seperti telah diketahui bahwa ANATES adalah program aplikasi analisis hasil tes/ulangan soal pilihan ganda atau uraian dalam bentuk validitas, reliabilitas, daya pembeda, dan indeks kesukaran (Admin, 2009).
Namun perlu diketahui bahwa jenis analisis butir soal yang digunakan dalam ANATES adalah menggunakan pendekatan model klasik. Permasalahan yang dialami oleh guruguru SMP Muhammadiyah 2 Karanglewas adalah kurangnya pemahaman mengenai jenis pendekatan analisis butir soal tes dan kesulitan dalam melakukan analisis butir soal tes terutama dengan memanfaatkan program komputer karena guru masih kesulitan dalam mengoperasikannya. Selain itu juga masih harus menerjemahkan/menafsirkan makna dari keluaran programnya. Oleh karena itu, dibutuhkan pendamping dalam menganalisis butir soal khususnya dalam menggunakan alat bantu program komputer.

Kegiatan pengabdian pada masyarakat ini bertujuan untuk memberikan pelatihan kepada tenaga pengajar (guru) SMP Muhammadiyah 2 Karanglewas Kabupaten Banyumas tentang pemanfaatan teknologi software komputer yaitu "QUEST" untuk membantu dalam menganalisis butir soal yang meliputi validitas, reliabilitas, daya pembeda, indeks kesukaran, dan daya pengecoh. Selain lebih cepat dibanding dengan penyelesaian dengan cara perhitungan manual, dengan menggunakan peralatan komputer, hasil perhitungan yang didapatkan juga akan lebih teliti.

Berdasarkan permasalahan yang dihadapi dan manfaat yang bisa diharapkan, maka dilaksanakan kegiatan pendidikan dan pelatihan (workshop) bagi guru-guru SMP Muhammadiyah 2 Karanglewas Kabupaten Banyumas. Workshop menggunakan program QUEST yang telah teruji dan memiliki kelebihan yaitu menyajikan hasil analisis berdasarkan teori tes modern (Subali dan Suyata, 2012). Workshop ini menggunakan metode ceramah, demonstrasi, tanya jawab (diskusi), dan praktik langsung menggunakan 
Hindayati Mustafidah, Harjono

perangkat komputer. Kegiatan diselenggarakan di laboratorium Komputer Program Studi Teknik Informatika - Universitas Muhammadiyah Purwokerto. Workshop ini direncanakan diikuti oleh 23 orang guru dari berbagai mata pelajaran dari 20 guru yang ditargetkan.

\section{METODE}

Guru SMP Muhammadiyah 2 Karanglewas terdiri dari 23 orang yang kesemuanya telah menyandang gelar sarjana. Kondisi ini telah cukup mendukung sebagai mitra kegiatan karena sudah bisa mengoperasikan komputer. Di samping itu, sarana dan prasarana di sekolah juga telah dilengkapi dengan laboratorium komputer.

Pelaksanaan kegiatan terbagi dalam 3 tahapan yaitu :

1. Tahap pendidikan dan pelatihan

Pada tahap ini dilaksanakan proses transfer pengetahuan dari instruktur kepada para peserta (mitra kegiatan) berupa:

a. Materi pengetahuan dasar tentang analisis butir soal.

b. Cara mengoperasikan program QUEST

c. Praktik menggunakan program QUEST

d. Menganalisis hasil keluaran program QUEST

2. Tahap pemantauan

Tahap pemantauan dilaksanakan di sekolah terhadap hasil pelatihan yang telah dilakukan dalam penerapannya di sekolah.

3. Tahap evaluasi

Pada tahap ini dilakukan evaluasi mengenai keberhasilan kegiatan sebagai outcome dari pelaksanaan kegiatan ini. Indikator ketercapaian dari keberhasilan kegiatan adalah para guru mampu menganalisis butir soal yang disusunnya.

Luaran yang dihasilkan dari kegiatan ini adalah berupa ketrampilan para guru dalam mengoperasikan program QUEST dan membaca serta menerjemahkan keluaran program. Selain ketrampilan, luaran kegiatan ini adalah sertifikat sesuai dengan kompetensi dalam memanfaatkan teknologi komputer dalam membantu melaksanakan salah satu kewajiban guru untuk melakukan evaluasi terhadap pembelajaran yang dilakukan.

\section{HASIL DAN PEMBAHASAN}

Kegiatan pengabdian pada masyarakat berupa pendidikan dan pelatihan dilaksanakan pada tanggal 16 Mei 2018 yang diikuti oleh 23 peserta dari guru-guru SMP Muhammadiyah 2 Karanglewas Kabupaten Banyumas (Gambar 1). Setiap peserta menerima kit, konsumsi, sertifikat, dan materi pelatihan berupa modul praktik dan software QUEST. Kegiatan ini terbagi dalam 3 tahapan yaitu: penyampaian materi, pemantauan, dan evaluasi. Sebelum penyampaian materi, dilakukan survei terhadap kegiatan asesmen kualitas soal tes yang dilakukan oleh guru. Hasil survei diperoleh informasi bahwa sebelum kegiatan ini, guru melakukan analisis butir soal dengan pendekatan klasik, di antaranya menggunakan program ANATES. Belum ada satupun guru yang menggunakan program QUEST. Dengan demikian dapat dikatakan bahwa pengetahuan dan kemampuan mengoperasikan program QUEST masih 0\%.

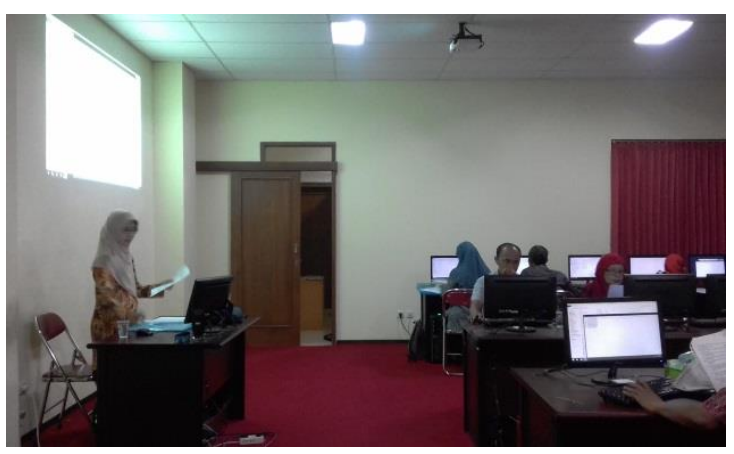

Gambar 1. Suasana pelatihan QUEST

Analisis butir soal terdiri dari 2 macam yaitu analisis secara klasik dan modern. Aspek yang perlu diperhatikan dalam analisis butir soal secara klasik adalah setiap butir soal ditelaah dari segi tingkat kesukaran butir, daya pembeda butir, dan penyebaran pilihan jawaban (untuk soal bentuk obyektif) atau frekuensi jawaban pada setiap pilihan jawaban. Penyebaran pilihan jawaban dijadikan dasar dalam analisis butir soal. Hal ini dimaksudkan untuk mengetahui berfungsi tidaknya jawaban yang tersedia. Suatu pilihan jawaban (pengecoh) dapat dikatakan berfungsi apabila 
pengecoh: 1) paling tidak dipilih oleh $5 \%$ peserta tes/siswa, dan 2) lebih banyak dipilih oleh kelompok siswa yang belum paham materi (Dikmenum, 2008).

Selain pendekatan model klasik, terdapat pendekatan lain dalam menganalisis butir soal yaitu pendekatan modern. Dalam pendekatan modern, penelaahan butir soal menggunakan Item Response Theory (IRT) atau teori jawaban butir soal. Teori ini merupakan suatu teori yang menggunakan fungsi matematika untuk menghubungkan antara peluang menjawab benar suatu soal dengan kemampuan siswa. Nama lain IRT adalah Latent Trait Theory (LTT), atau Characteristics Curve Theory (CCT). Asal mula IRT adalah kombinasi suatu versi hukum phigamma dengan suatu analisis faktor butir soal (item factor analysis) kemudian bernama Teori Trait Latent (Latent Trait Theory), kemudian sekarang secara umum dikenal menjadi teori jawaban butir soal (Item Response Theory) (McDonald, 1999). Model IRT seperti yang disampaikan oleh Hambleton et al (1991) terdiri dari: 1) model satu parameter (Model Rasch), yaitu untuk menganalisis data yang hanya menitikberatkan pada parameter tingkat kesukaran soal, 2) model dua paremeter, yaitu untuk menganalisis data yang hanya menitikberatkan pada parameter tingkat kesukaran dan daya pembeda soal, dan 3) model tiga parameter, yaitu untuk menganalisis data yang menitikberatkan pada parameter tingkat kesukaran soal, daya pembeda soal, dan menebak (guessing).

Komputer sebagai alat bantu menghitung ternyata masih dirasa sulit bagi sebagian guru untuk melakukan penilaian terhadap kualitas soal yang dibuat. Hal ini disebabkan karena harus mengumpulkan data skor hasil pekerjaan siswa yang diberi tes, kemudian hasil perhitungan dianalisis, yang selanjutnya dilakukan perbaikan-perbaikan terhadap soal yang telah disusun (jika perlu diperbaiki). Hal inilah yang juga dirasa terlalu banyak pekerjaan yang harus dilakukan. Hasil studi yang dilakukan Widodo (2010) menyebutkan bahwa guru enggan melaksanakan penilaian soal tes, karena selain tidak memiliki waktu luang karena jam mengajarnya penuh, juga karena belum atau bahkan tidak mengetahui manfaat dari melakukan asesmen soal tes. Keengganan guru menggunakan komputer sebagai alat bantu untuk melakukan asesmen kualitas soal tes juga disebabkan kurangnya penguasaan guru terhadap pengoperasian komputer. Selain itu, guru merasa tidak ada tuntutan untuk melakukan asesmen. Hal ini tidak sejalan dengan peraturan pemerintah yang tertuang dalam Permendiknas No. 20 Tahun 2007 yang mengatakan bahwa "... dari segi teknik dan instrumen penilaian yang digunakan, setiap satuan pendidikan dituntut memiliki guru yang mampu melakukan pengujian pendidikan dengan instrumen yang benar-benar akuntabel".

QUEST sebagai salah satu jenis program komputer dibangun untuk membantu melakukan analisis butir soal menggunakan pendekatan modern 1 parameter. Dengan berbagai kelebihan dan kekurangannya, program QUEST telah banyak diimplementasikan di lingkungan pendidikan di Indonesia. Materi tentang program QUEST dalam kegiatan ini meliputi cara mengoperasikan program QUEST dan menganalisis atau membaca hasil keluaran program QUEST.

Target dalam kegiatan ini adalah guru memiliki kompetensi di salah satu bidang kompetensi pedagogik yaitu kompetensi pemanfaatan teknologi dalam pembelajaran berupa ketrampilan menggunakan program komputer QUEST dalam menganalisis butir soal tes. Evaluasi sebagai tahap akhir dari pelaksanaan kegiatan ini, dilakukan untuk mengetahui keberhasilan kegiatan sebagai outcome dari pelaksanaan kegiatan. Indikator ketercapaian dari keberhasilan kegiatan adalah para guru mampu menganalisis butir soal yang disusunnya. Dari 23 guru yang hadir sebagai mitra kegiatan, dicapai hasil sebanyak 20 orang yang berhasil menguasai cara mengoperasikan dan membaca hasil program QUEST atau sebanyak $86,96 \%$. Hal ini menunjukkan terjadi peningkatan pengetahuan maupun ketrampilan para guru setelah mengikuti kegiatan dibanding dengan saat sebelum mengikuti kegiatan. Meskipun berasal dari berbagai latar belakang keilmuan, para guru sangat antusias dan bersemangat dalam mengikuti pelatihan ini 
meskipun sedikit mengalami kendala dalam menyusun instruksi yang dipersyaratkan dalam program QUEST. Kesulitan yang dialami oleh beberapa guru (13\%) terkait dengan penggunaan program QUEST ini adalah dalam membaca dan menganalisis hasil keluaran program QUEST. Penyebab utama adalah guru baru mengenal program QUEST ini sebagai alat bantuanalisis soal tes yang menggunakan metode modern yaitu metode IRT (Item Respons Theory) atau Teori Respon Butir.

\section{SIMPULAN}

Kegiatan pengabdian pada masyarakat dalam bentuk pelatihan penggunaan program QUEST untuk menganalisis butir soal tes dapat meningkatkan profesionalisme guru yang dibuktikan dengan meningkatnya kemampuan guru dalam melakukan asesmen kualitas soal tes dan bertambahnya pengetahuan serta ketrampilan dalam pemanfaatan perkembangan teknologi komputer.Berdasarkan hasil evaluasi kegiatan ini dan diskusi serta wawancara dengan beberapa peserta, disarankan kepada para guru untuk selalu melakukan analisis terhadap soal tes yang disusunnya sehingga mutu soal dapat terjaga dalam rangka meningkatkan mutu pendidikan di negara kita. Sebaliknya, para guru menyarankan kepada pelaksana kegiatan dalam hal ini pihak Universitas Muhammadiyah Purwokerto untuk selalu bisa memberikan transfer ilmu kepada masyarakat khususnya masyarakat kependidikan dalam pemanfaatan teknologi komputer.

\section{UCAPAN TERIMA KASIH}

Penulis mengucapkan terima kasih kepada Universitas Muhammadiyah Purwokerto melalui Lembaga Penelitian dan Pengabdian pada Masyarakat yang telah memberikan kesempatan, dana, dan fasilitas untuk melaksanakan kegiatan pendidikan dan pelatihan ini.

\section{DAFTAR PUSTAKA}

Admin, 2009, Taksonomi Bloom: Mengembangkan Strategi Berpikir Berbasis TIK, http://gurupembaharu.com/pembelajar an_/perencanaan_/taksonomi-bloom- mengembangkan-strategi-berpikir-

berbasis-tik/ diakses tanggal 26 Desember 2009.

Bennyarsih, C., 2006, Korelasi Antara Pembelajaran Remidial dengan Pencapaian Tujuan Pembelajaan Mata Pelajaran PKnPS Pokok Bahasan Perjuangan Melawan Penjajah dan Pergerakan Nasioal pada Siswa Kelas V SD Negeri Segugus Pamuji UPK Karanglewas Semester II Tahun Pelajaran 2005/2006. Skripsi, FKIP UMP. Purwokerto.

Dikmenum, 2008, Panduan Analisis Butir Soal.www.dikmenum.go.id/ dataapp/kurikulum/ 5.\%20perangkat\%20penilaian\%20ktsp $\% 20 \mathrm{sma} / 6 . \% 20$ analisis\% 20butir\%20soal/panduan\%20analisis \%20butir\%20soal.doc, diakses 20 Nopember 2008.

Dwiningsih, Y., 2006, Analisis Sistem Evaluasi Kurikulum 2004 Beberapa SMA Swasta pada Mata Pelajaran Biologi Kelas X Tahun Pelajaran 2004/2005 di Kabupaten Banyumas, Skripsi, FKIP Universitas Muhammadiyah Purwokerto, Purwokerto.

Haladyna, T. M. and Rodriguez, M. C. (2013) DEVELOPING AND VALIDATING TEST ITEMS. New York: Taylor \& Francis.

Hambleton, R. K., Swaminathan, H. and Rogers, H. J. (1991) Fundamentals of Item Response Theory. 1st edn. London: SAGE Publications, Inc.

Hanafi, A. and Suhardi (2014) 'KARAKTERISTIK BUTIR SOAL UN BAHASA INGGRIS SMK DI KABUPATEN TABALONG KALIMANTAN SELATAN TAHUN AKADEMIK 2010/2011', LingTera, 1(1), pp. 1-14.

Hani, D.F., 2006, Analisis Butir Soal Akhir Semester Genap Kelas X Bidang Studi Biologi Kurikulum 2004 Tahun Pelajaran 2005/2006 di SMA Negeri 
Kabupaten Banyumas. Skripsi. FKIP Universitas Muhammadiyah Purwokerto, Purwokerto.

McDonald, R.P., 1999, Test Theory: A Unified Treatment, Larvrence Erbaum Associates, Publishers, New Jersey.

Mustafidah, H. dan Pinandita, T., 2011, Pelatihan Pemanfaatan Komputer sebagai Alat Bantu Menganalisis Butir Soal Tes, Laporan Pengabdian pada Masyarakat, Lembaga Penelitian dan Pengabdian pada Masyarakat Universitas Muhammadiyah Purwokerto, Purwokerto.

Nuswowati, M. et al. (2010) 'PENGARUH VALIDITAS DAN RELIABILITAS BUTIR SOAL ULANGAN AKHIR SEMESTER BIDANG STUDI KIMIA TERHADAP PENCAPAIAN KOMPETENSI', National Scientific Journal of UNNES, 4(1), pp. 566-573. Available at: https://journal.unnes.ac.id/nju/index.p hp/JIPK/article/view/1314.

Raharja, N. S. (2014) 'ANALISIS BUTIR SOAL UJIAN AKHIR SEKOLAH PRODUKTIF PEMASARAN KELAS XII PEMASARAN SMK NEGERI 9 SEMARANG', Economic Education Analysis Journal, 3(3), pp. 564-569.

Rahmasari, D. and Ismiyati (2016) 'ANALISIS BUTIR SOAL MATA PELAJARAN PENGANTAR ADMINISTRASI PERKANTORAN', Economic Education Analysis Journal, 5(1), pp. 317-330.

Sari, R.D.P., 2006, Evaluasi Kualitas Soal Ujian Akhir Semester Genap Mata Pelajaran Biologi Kelas X Tahun Pelajaran 2004/2005 di SMA Negeri 3 Purwokerto, SMA Negeri 4 Purwokerto, dan SMA Negeri Sokaraja, Skripsi, FKIP Universitas Muhammadiyah Purwokerto, Purwokerto.

Subali, B. dan Suyata, P., 2012, Pengembangan Item Tes Konvergen dan Divergen:
Penyelidikan Validitasnya secara Empirik, Diandra Pustaka Indonesia, Yogyakarta.

Suwarsito dan Sutomo, 2009, Pelatihan Menentukan Kualitas Soal (Validitas dan Reliabilitas) Menggunakan Alat Bantu Komputer bagi Guru-Guru di Kabupaten Banyumas, Laporan Pengabdian pada Masyarakat, Lembaga Penelitian dan Pengabdian pada Masyarakat Universitas Muhammadiyah Purwokerto, Purwokerto.

Uno, H. B. dan Koni, S., 2012, Assessment Pembelajaran, Bumi aksara, Jakarta.

Widodo, 2010, Analisis Butir Soal Tes, Jurnal Pendidikan Penabur, No.14/Tahun ke9/Juni 2010, halaman $58-67$.

Yusuf, A. M., 2015, Asesmen dan Evaluasi Pendidikan: Pilar Penyedia Informasi dan Kegiatan Pengendalian Mutu Pendidikan, Prenadamedia Group, Jakarta. 